\title{
Abstract
}

This article analyses risk, value and responsibility in a high wire cycling stunt which took place in Brooklyn in 1897. The stunt involved the performer's bicycle completing an electrical circuit to illuminate his body and wheels with coloured lights, using electricity siphoned from a nearby Brooklyn trolley route. I explore the connections and distinctions between stunts and circus, and the status of risk and responsibility in each. I then analyse what is known about the contract between the performer and the railroad company, and the types of exchange it involved. I compare these modes of exchange and investment to Randy Martin's concept of a 'derivative', which encompasses a mode of sociality as well as a type of financial investment. Martin argued for conjoint critiques of performance and value abstractions, holding that the 'intricate acrobatics of high finance have all manner of parallel expression in dances on the ground'. Pursuing this parallel between bodily movement and value abstraction, I read this bicycle act, and stunts more broadly, as embodied derivatives.

Key Words

Stunt High-wire Bicycle Derivative Electricity Circus 
Luminous Connections: Risk, Value and Responsibility

In A Late Nineteenth-Century High Wire Bicycle Stunt

Live Wire

In the mid-1890s, train lines in Brooklyn were changed from being powered by steam to being powered by electricity. ${ }^{1}$ An aerial performer took advantage of this new amenity in his high wire act in Ridgwood Park, Queens County, in 1897. Performing under the alias 'Professor Arion', Frank McDonald or Frank Donahue or D. H.

McDonnell (sources disagree as to his name) cycled across a wire between 60 and 75 feet from the ground, before an audience of two or three thousand. ${ }^{2}$ The name 'Arion' is taken from a winged horse in Greek mythology, paralleling the hybridity of the man/bicycle in the air, and echoing an affinity between flight and aerial acts common in circus practice and discourses. ${ }^{3}$

Drawing electricity from the nearby train lines, 'Arion' connected to the live wire via his bicycle wheels, which were made of grooved metal. The New York Tribune described:

When 'Arion' mounted the wire from a small platform built around the top of the pole, all eyes were upon him. Small incandescent lights were so arranged about his clothing and the wheel that they illuminated as soon as the electrical current was touched. 'Arion' was to ride 100 yards. $^{4}$

McDonald/Donahue/McDonnell was apparently an experienced dare-devil performer, who had attracted some attention by walking a narrow plank over Niagara Falls a few years before. Twenty-eight years old, he lived in Fort Wayne, Indiana, and had a wife 
and small child. ${ }^{5}$ Having recently performed his bicycle act near a railway line in San Francisco, McDonald/Donahue/McDonnell had been engaged by the Brooklyn Heights Railroad Company for a seven-night run, and had completed the act successfully the night before this performance. ${ }^{6}$

Exactly who was responsible for the show was a matter of intense debate in the aftermath, because it went badly wrong. The Tribune details:

He had gone about a quarter of the distance when he was seen to topple off the wheel, and both man and bicycle fell to the ground.... A call was sent to St. Catherine's Hospital, Brooklyn, but he was dead before it was responded to. ${ }^{7}$

The Brooklyn Daily Eagle published the results of an autopsy, which concluded that McDonald/Donahue/McDonnell had died of electric shock, suggesting that the voltage was higher than intended. ${ }^{8}$ The Brooklyn Heights Company argued, however, that it was mechanically impossible for the charge to be higher than $\mathbf{5 5 0}$ Volts. Nonetheless, the Eagle accused both the Company and the manager of the park of negligence, because there had been no net under the wire. ${ }^{9}$ Under the New York Penal Code, proprietors were obliged to provide a net for acrobatic exhibitions (an example of increasingly protective and proscriptive performance legislation). The Company blamed the manager of the park, claiming that he had employed McDonald/Donahue/McDonnell; meanwhile, the manager of the park blamed the Company, claiming that the only existing contract was between it and the performer. ${ }^{10}$ In response to questioning from an Eagle reporter, the Company stated that in the contract, McDonald/Donahue/McDonnell had: 
'formally released the company from any damage or injury arising out of the performance. All the railroad company agreed to do was to put up the wires and furnish a current of 500 volts. Prof. Arion was to do all the rest and to take upon himself the sole responsibility. ... [T] he railroad company had nothing to do with last night's fatal performance.' 11

The spokesman went on to say that the performer had come 'highly recommended' by managers of railroad companies in the West. McDonald/Donahue/McDonnell was effectively blamed in this account for his failure to overcome the risk as promised, while the Company was presented as the provider of 'opportunity'. ${ }^{12}$ The statement referred to McDonald/Donahue/McDonnell as 'Prof. Arion' throughout, in spite of the general passenger agent having eaten dinner with him a couple of nights before. This textual slip suggests that the Company had taken at face value — or wished to imply that it had - the 'fictional' aspect of what Thomas Postlewait terms the 'double identity of a performance event', thereby eliding the material conditions of the event. ${ }^{13}$ The artist's fictional capacity to overcome the risk of his precarious act entirely had shaped the act's material organisation.

In the introduction to a special issue of The Drama Review on precarity in 2012, Nicholas Ridout and Rebecca Schneider invoked precarity as a state of performing bodies and a condition of life and work. As well as an act which teeters on an edge, precarity expresses the conditions of its creation: a pervasive state of uncertainty. In such circumstances, precarity holds out a 'kind of promise' which reaches towards innovation and creativity, and intertwines them with risk. Physical stunts such as this one are paradigmatic acts of precarity: 'embodied balancing act[s]', which situate opportunity on a borderline between life and death. ${ }^{14}$ 
The Company seemed to take seriously McDonald's undertaking: that precarity could be invited, yet at the same time entirely negated, through the skill of an individual body.

This article focuses on a nexus of risk, value and responsibility in this bicycle stunt. I explore the connections and distinctions between stunts and circus, and the status of risk and responsibility in each. I then analyse what is known about the contract between McDonald/Donahue/McDonnell and the Brooklyn Heights Railroad Company, and the types of exchange and investment it involved. Finally, I compare these modes of exchange and investment to dance scholar Randy Martin's concept of a 'derivative', which encompasses a mode of sociality as well as a type of financial investment that gained prominence in late nineteenth-century stock markets. Martin outlined his concept in relation to dance and present-day precarity in 'A Precarious Dance, A Derivative Sociality', arguing that the 'dynamics of the derivative can be seen across all manner of human activity in ways that engender mutual indebtedness' ${ }^{15}$ Martin argued for conjoint critiques of performance and value abstractions, holding that dance is 'a key site in which bodies in movement make value' and that the 'intricate acrobatics of high finance have all manner of parallel expression in dances on the ground'. ${ }^{16}$ Pursuing this parallel between bodily movement and value abstraction, I put both Martin's derivative and Karl Marx's concept of 'fictitious capital' into critical dialogue with the material conditions and aesthetics of McDonald/Donahue/McDonnell's bicycle act. $^{17}$

Stunts and Circus

High wire bicycle or velocipede acts had been a popular feature of circuses and carnivals in the United States for the previous two decades. Peta Tait cautions against 
stories of 'aerial firsts'; in the 1890s, however, St Paul Daily Globe believed that aeronauts Harry Gilbert and 'Prof. Donaldson', who had run Buffalo Bill's advertising hot air balloons, were responsible for the first high wire cycling exhibition in the country. ${ }^{18}$ In the early 1880 s, French aerialist Ella Zuilla (sometimes called Zuila or Zola), the 'female Blondin', toured a high-wire velocipede act with Adam Forepaugh's circus. ${ }^{19}$ For the next two decades, female and male high wire bicycle acts performed widely, including Alferetta Adair, 'Davenport', 'Herbo', duo George Zurella and Emma Dubois, and troupes such as the Melrosas, the Charest Family, Geo. Scott and Family, Professor Baum and his troupe, the Forepaugh family, and several companies from Tokyo. ${ }^{20}$

McDonald/Donahue/McDonnell's addition of electricity was highly novel, and indicative of nineteenth-century circus's function, in Matthew Wittman's words, as a 'forum for new technologies'. ${ }^{21}$ Helen Stoddart describes circus's relationship with electricity as constitutive of its historical alignment with the 'spirit of modernity' and technological innovation, pointing out that the first public display of arc electric lighting took place in a light parade and the illuminated ring of Howe's London Circus, Sanger's Royal Menagerie and Cooper, Bailey and Company’s International Allied Shows on 15 April $1879 .{ }^{22}$ Subsequently, electric lighting was widely adopted and puffed in circus advertisements: in 1883, John Robinson's Big Show was 'Made as bright as the noon-day sun by the $\$ 30,000$ Brush Electric Light!' ${ }^{23}$ In a dynamic intrinsic to circus performance, McDonald/Donahue/McDonnell's bicycle act brought fascination with electrical spectacle to bear on a single body. It staged the incorporation of the performer into an electrical circuit, exemplifying Stoddart's view of circus's tendency to 'dramatise the frenetic, dangerous, spectacular and shocking energies of a modern secular world' in a manner which (when successful) enacted the potential of human bodies to be 'enriched by such encounters'. ${ }^{24}$ A similar electrified act appeared 
in 1900 in Atlantic, Iowa, where 'Davenport' provided a 'magnificent illuminated display at night, riding a bicycle on a high wire'. ${ }^{25}$

Electrical novelty is one of several ways in which McDonald/Donahue/McDonnell's act can be read as a one-man embodiment of turn-of-the-century American circus. The performance took place at the height of large-scale railroad circus; that year, Janet M. Davis writes, each major circus was transported by scores of railcars carrying as many as a thousand labourers and performers, human and animal. ${ }^{26}$ Such colossal scale was enabled by the development of the railway network itself, which had standardised and rationalised, becoming a 'powerful cultural icon of a new modern nation-state'. ${ }^{27}$ McDonald/Donahue/McDonnell's act was an off-shoot of the railway network, siphoning its power and using its architectural structures for a stage. Indeed, his stunt assembled the parts of a railway in a stripped back or metonymic form: it put wheels on a rail and electrified them.

I have termed this high wire performance a 'stunt', adopting a word which was coming into common use in New York slang at this time. Stunts are frequently referred to in circus scholarship to convey both dangerous, skilful acts and attention-grabbing promotional mechanisms. ${ }^{28}$ Efforts to define 'circus' intertwine with those aimed at defining 'stunts' to the extent that stunts could be understood as simply a subset or specific instance of circus. Both are concerned with bodies in danger, and feature virtuosic physical skill. Both have traditionally been considered 'low', commercial art forms (if they are termed art at all) and tend to share a sense of absurdity and frivolity. Both bring simultaneous and conflicting connotations of authentic danger and illusion or trickery. ${ }^{29}$ 
Stunts and circus also have a common and intimate affinity with advertisement.

Stoddart argues that advertising is part of circus's 'art as well as its machinery'. ${ }^{30}$ Most obviously, Stoddart means that circus posters had substantive aesthetic qualities. More broadly, she emphasises the mutually reliant development of circus and advertising practices, citing 'stunts' and 'public relations exercises' as circus's key advertising forms (along with print). ${ }^{31}$ Live performances were a crucial aspect of the blossoming advertising industry in New York and other American urban centres in the late nineteenth century. ${ }^{32}$ Where the performing arts were concerned, in vaudeville, for example, live advertising sometimes made the act advertised and the advertisement difficult to separate. Though performers and critics referred to their stage acts as stunts, Edward Renton's early twentieth century manual for theatre managers listed vaudeville performers who were willing to do their acts not only on stage but also as 'special stunts' in other public places, diving from bridges or balancing on high corners of buildings. ${ }^{33}$ The term 'stunt' is marked by its ability to express both the act and the selling machine.

While close affinities between circus and stunts exist, stunts are also distinct from circus. Historically, the term 'stunt' in the sense of feat only came into use at the end of the nineteenth century and it was not particularly associated with circus acts. ${ }^{34}$ Though 'stunt' could be used to describe a handstand, it also conveyed sensational journalism, political campaigns, and acts in everyday life. ${ }^{35}$ While danger and skill are at the core of circus, the skill and danger of a late nineteenth-century stunt performance existed primarily to attract attention, a role that might also be fulfilled by other forms of sensation or controversy.

McDonald/Donahue/McDonnell's bicycle performance, then, was a circus-style act in that it embodied absurdity and sensation and was 'a vehicle for the 
demonstration and taunting of danger'. ${ }^{36}$ It was also a 'stunt' as distinct from circus, because these qualities were put into service not only for the sake of excitement and entertainment, but also for the promotion of another, unconnected entity. The significance and function of McDonald/Donahue/McDonnell's endangered body was altered, because it was put at risk to increase the value of an unrelated organisation, the Brooklyn Heights Railroad Company. To employ Martin's terms, the act entangled performer and Company in a contested state of mutual indebtedness.

The Company had organised 'Arion's' performance as part of its Hessian Volkfest celebrations, a public access event which served as a form of promotion for the Company. Such events were part of a new drive among railroad companies to entertain and attract potential customers: the Street Railway Journal reported that managers who were 'awake to the interests of their roads' were 'anxious to keep novelties before the riding public'. ${ }^{37}$ It was common for railroad operators to manage or lease adjoining parks, and their individually-owned electrical power plants presented new opportunities for engaging the public: the Railway Journal weighed up the pros and cons of installing an electric fountain for entertainment. McDonald/Donahue/McDonnell's aerial performance highlighted the Company's new technological feature. Both performer and Company traded on the novelty of their electrical connections, spectacularised by McDonald/Donahue/McDonnell's body at risk.

Such leveraging made use of, and also altered, the invocation of responsibility in circus acts. Stoddart describes this as the 'expansion and contraction' of circus's performance 'frame' through endangerment of performers, whereby audience members recognise and feel some responsibility for the artists' 'proximity to human extinction, rather than merely untruth' (as might be the case in realist theatre). The experience of watching 
circus, Stoddart suggests, makes a distinct claim on a spectator's sense of responsibility. ${ }^{38}$

Removed from the ring and instrumentalised as advertisement in the late nineteenth century, circus stunts retained their capacity to invoke responsibility, and by the extremity of the exploitation frequently on display, pushed to the fore conflicts concerning freedom and safety. Hence dangerous promotional acts took on a particular social resonance; a capacity to reveal a general state of precarity and mutual indebtedness, and raise widely applicable questions about whether and how lives ought to be protected.

Because of stunts' association with several performing arts (circus, vaudeville, film) and other cultural performance forms (advertisement, political campaigns, sport), the risks attendant on them tend to be more conceptually unwieldy than those associated with a circus act undertaken within a circus frame. This is not to suggest that one is more dangerous than the other, but rather that it is not always clear what framework should be brought to bear on stunt performances, and this ambiguity complicates how risk signifies and what social function it serves. Writing on female stunt pilots, Mary Russo celebrated stunts' potential to celebrate autonomy and empower marginalised actors, and at the same time warned of stunts' capacity to mark those who undertook them as inherently risky. Russo described a stunt as 'a tactic for groups or individuals in a certain risky situation in which a strategy is not possible' (drawing on Michel de Certeau's theorisation of everyday life). Note that as in Ridout and Schneider's definition of precarity, risk here becomes a condition of production as well as a quality of the act produced. While embracing stunts' capacity to celebrate freedom, Russo also warned that through stunts, performers could come to embody riskiness, exacerbating the sense that they were in themselves always and already risky. Russo framed this as 
stunts' tendency to 'perpetuate the blaming, stigmatization, and marginalizing of groups and persons'. ${ }^{39}$ Springing from a condition of precarity, stunts could justify and further that condition.

I'll now to turn to how the contract between McDonald/Donahue/McDonnell and the Company structured their exchange and mutual indebtedness.

Contracts: A Romance of the Market

The contract between 'Prof. Arion' and the Brooklyn Heights Railroad Company involved two types of exchange, which accorded McDonald/Donahue/McDonnell two different roles.

On the one hand, $\mathrm{McD}$ onald/Donahue/McDonnell was a labourer. He earned a wage for his work and was directly employed by the Company, in spite of the spokesman's efforts to depict the act as benefiting nobody but the performer. If we read this in terms of Karl Marx's conception of industrial production, McDonald/Donahue/McDonnell's abstract labour was bought by the Company for a wage, and his surplus labour was the source of the surplus value the act created. ${ }^{40}$ The aim of the Company was to increase its value through the act.

On the other hand, McDonald/Donahue/McDonnell was given an 'opportunity' to increase his own value as a performing artist. Opportunity — precarity’s promise implies money, but while money is 'pure quantity', opportunity approaches immeasurability. ${ }^{41}$ An opportunity might give rise to more opportunity, becoming an ongoing condition which perpetually renews itself. In that sense, both the Company and 
McDonald/Donahue/McDonnell offered something that approached immeasurability in the contract. In this capacity, McDonald/Donahue/McDonnell performed the function of 'commodity capital' in Marx's schema; he was one of the commodities which came out with increased value at the end of the production process. ${ }^{42}$

Such ability to secure fees for further work in the future has been termed 'human capital', a concept developed by the 'Chicago School' of neoliberal economists, particularly Gary Becker, in the 1950s and '60s. In Michel Foucault's The Birth of Biopolitics, a series of lectures given at the College de France in 1978 and 1979, Foucault framed 'human capital' as a progression of biopolitical governance and an example of the 'grid' of economic thinking expanding to cover all aspects of human life. ${ }^{43}$ In this model, the wage labourer is not dependent on a company to facilitate their work. Instead, they are the entrepreneurs of themselves, with full responsibility for the investment of their own capital (in spite of their not owning the means of production). There is a broad historical parallel between the developments Foucault describes - the neo-liberal, late capitalist structures that increasingly took hold in the second half of the twentieth century - and the liberal political and economic ideology of the late nineteenth century. In both cultures, the entrepreneur becomes an ideal model of selfsufficient growth.

The Company's reaction to McDonald/Donahue/McDonnell's death demonstrated its interest in emphasising its role as provider of opportunity (or means of production), and restricting both responsibility and impact to McDonald/Donahue/McDonnell as an individual. Clearly, this avoided the social questions in play, such as, what responsibilities did a company have towards its employees? What role did government and the law have in this relationship? 
Instead of instating a condition of mutual reliance, the contract created an ideal, selfreliant subject. Writing on turn-of-the-century consumer culture, Mark Seltzer argues that the 'self-made character of the commercial person' in liberal culture is an embodiment of the 'contract, and the forms of possession and self-possession, it entails'. ${ }^{44}$ Interestingly, for McDonald/Donahue/McDonnell, his 'self-possession' seems to have been enacted under the name of his persona, Professor Arion. He 'possessed' himself as someone else, as a character. This is an absurd extension of the condition of having a 'character' in market culture, in the sense of creating a person who is able to make good on promises. Seltzer argues that neither the contract nor the notion of the market register the emerging conditions of identity at the turn of the century, which Seltzer frames as involving intimate couplings of bodies and machines and the simultaneous reduction of individuals to sheer materiality and total abstraction. ${ }^{45}$ Seltzer holds that the anachronistic subjectivity that contracts promised may be precisely why they exerted a particular fascination at this historical moment. ${ }^{46}$

Such fascination stems, in Seltzer's view, from tension between two rival models of the individual in turn-of-the-century American consumer society: 'the model of competitive individualism, on the one side, and disciplinary individualism, on the other'. Seltzer characterizes these models as 'market culture' and 'machine culture' and is particularly interested in what he terms the 'romance of the market in machine culture' and the ways in which that romance became 'functional' in consumer society. ${ }^{47}$ The 'romance of the market' constructed an ideal free subject, solely responsible for themselves and their investments. Within emerging monopoly capitalism, then, an idealised concept of market individualism became productive, precisely because of the frisson it created with emerging machine culture. At a point in which interconnection was increasingly systematised, individual feats, responsibilities and freedoms become particularly attractive and operable, not as a point of opposition, but rather as a complementary 
fantasy.

Circus epitomised such friction between market and machine culture: circus owners, Davis argues, were major exponents of entrepreneurialism and the 'ideal of the selfmade man', yet circus companies were exemplary of the disciplinarian, strictly timemanaged work cultures which would come to be associated with Frederick Taylor and Henry Ford. ${ }^{48}$ The development of industrial trusts and monopolies which took hold in late nineteenth-century United States was mirrored by 'combination' circuses. ${ }^{49}$ Circus presented an 'intimate look at the logistics and ideology of the new industrial order', Davis writes, yet at the same time evoked a 'pre-industrial world' where humans and animals could still outstrip machines. ${ }^{50}$

As well as risk to his life, a key source of drama in 'Arion's' act was tension between a spectacle of human self-reliance, and a spectacle of incorporation into disciplined systems. As a risky solo, the feat spoke to a glorious autonomy, beautified by precarity, but it was also embedded in and enabled by the infrastructure of the city, with its attendant ties to society, government and business. Because its novelty lay in connections, the act threw into relief the systems that brought it into being, and 'Arion's' place within them:

$[\mathrm{H}] \mathrm{e}$ started over the wire, making connections, so that his clothing and bicycle, which were decorated with incandescent lamps of various colors, blazed with great brilliancy. As McDonnell glided out on the wire his body was thrown into strong relief by the blaze from the wheel .... ${ }^{51}$

Pulled between ideal individualism, on the one hand, and on the other, fascination with the increasingly interconnected material cultures of urban modernity, the act invoked a 
form of metropolitan incandescence, a literal and figurative radiance, which derived from the system, but was transferred to the person poised within it.

\section{Electric Sacrifice}

The thrill of McDonald/Donahue/McDonnell's performance drew on his audience's understanding of electrical high wires as both a wonder and a public danger; their liveness and deadliness. Disputes about responsibility for safety were manifold in the developing electrical network. Live overhead wires had caused accidents and deaths in Brooklyn and New York since the early 1880s. Though legislation prescribed the burial of electrical wires, disagreements about who should pay meant that in 1897 many wires still hung overhead. ${ }^{52}$ Electricity's deadliness had been underlined when, after a series of experiments on animals (sometimes before a live audience), alternating current was adopted as New York's means of instituting the death penalty in $1889 .{ }^{53}$ Thomas Edison and other direct current advocates had been a major influence on this decision, causing some commentators to decry the fact that the deadly workings of the state had been hijacked for the purpose of 'business advertisement', becoming a state-sponsored spectacle which served the established electrical industry. ${ }^{54}$

In spite of the danger they posed, high wires also provoked wonderment at connectivity. Seltzer describes turn-of-the-century amazement at the sense of the 'pure present conveyed by the electric technology's 'magical' and lightning transgression of the barriers of time and distance'. ${ }^{55}$ In an official history of the New York Stock Exchange published in 1905, for example, Edmund Stedman recorded an impression of an English visitor eighteen years previously (in 1882): 
$[\mathrm{H}] \mathrm{e}$ saw a sight that instantly gave him a realization of the extent of our peopled territory, and of the meaning of the Stock Exchange as the focus to which all currents of American purpose and energy converge. It was shortly before the time when the wires of New York's electric system were buried, by enactment, out of sight. Through the air, over New Street, hundreds, seemingly thousands, of these wires stretched toward the Exchange. No bird could fly through their network, a man could almost walk upon them .... 56

Not yet concealed underground, the electric wires made the vast connectivity of the Stock Exchange explicit and awe-inspiring; Stedman held it up as evidence of the arrival of 'modern high finance'. ${ }^{57}$ The Exchange's electric wires were a vision of unceasing circulation of information, money and commodities. Stedman's description invites a conflation of the 'currents' of human energy, electrical currents and the circulation of currency, or capital. Paradoxically, the mass of entangled wires presented in sensual, tangible form the ethereal quality of both electricity and capital. Electricity was a commodity that appeared to transcend its status as commodity, akin to money. Like paper currency or credit in Marx's schema in Capital, electrical currents invoked a dematerialized medium of circulation, a movement both instantaneous and constant. ${ }^{58}$ Rather than displaying itself, electricity had the effect of illuminating commodities around it and facilitating their interconnections and exchange.

McDonald/Donahue/McDonnell's performance spectacularised the bicycle's turning wheels, and its most thrilling element was the completion of an electric circuit, such that the performer's body mingled with, and was subsumed into, that circuit. It was an enactment and celebration of circulation, shadowed by the fatal circulation of electricity through human bodies in the form of execution. 
The act was also concerned with putting McDonald/Donahue/McDonnell into circulation and abstracting him into a commodity, suggestive of Seltzer's conditions of identity in machine culture. On such abstraction of self, Martin wrote: 'What we call identity is certainly an attribute of self that gets bundled, valued, and circulated beyond an individual person'. ${ }^{59}$ Martin situates this tendency to stratify and value identity in the dynamics of the derivative. The term derivative has multiple applications in McDonald/Donahue/McDonnell's performance and its context, and is more broadly a useful analogy for conceptualising stunts and value.

\section{Stunts and Derivatives}

In its broadest sense, derivative refers 'to the transmission of some characteristic from an originating source to a consequent site, expression, or manifestation', as in the verb, to derive. ${ }^{60}$ A derivative is also a specific financial mechanism, one which developed intensely in the final decades of the nineteenth century. In the 1880s (as in the present) derivatives were called 'futures' and they were the subject of debate and legislation. Purchasing a 'future' meant buying an option to buy a product or stock at a fixed price, at a fixed date in the future. Effectively this was a gamble on the price rising or falling, and it massively expanded trade in stock exchanges: 'The number of those who devote their whole time and energies to transactions, which are nothing but bets on the future prices of commodities, has become enormous,' a financial journalist reported in $1883 .{ }^{61}$ By the mid 1880s, futures were the 'main business transacted at the exchanges'. ${ }^{62}$ Derivative investments are generally framed as means of offsetting a risk involved in a specific investment, which many argue has an overall, societal effect of increasing risk. Martin writes that a derivative 'both particularizes certain risks and generalizes a condition of risk', both 'anticipate[s] and encourage[s] volatility'. ${ }^{63}$ Derivatives are 
concerned with expanding the possibilities of circulation - creating an entirely new, related and dependent orbit in which circulation can take place.

Derivatives also consist of yoking together two unrelated functions, and making one dependent on the other, enabling unexpected leveraging and extraction of value.

In banking journals, the development of futures was greeted with suspicion and strong efforts to distinguish between gambling contracts, which were legally void, and contracts made for the 'actual delivery of merchandise' ${ }^{64}$ Writers in banking magazines called futures transactions 'fictitious' and 'unproductive'. ${ }^{65}$ They served only to 'make uncertainty still more uncertain', to cause 'defalcation, breach of trust, or unexpected insolvency'. ${ }^{66}$ One 1882 columnist reflected: 'it is evident that by thus increasing the hazard of business, life is made less joyful, the strain is increased, the life-threads are sooner snapped. ${ }^{67}$ It was widely understood that derivatives stood to make living more precarious; this commentator argued against them on the grounds of protecting life and happiness. Yet proponents of these 'quicker and less unelastic trade systems' argued that a pragmatic trader could hardly afford to ignore them. ${ }^{68}$

Marx would situate derivative investments in the realm of fictitious capital, in which he placed all stocks and bonds. Stocks derived their value from actual capital, but became free-floating, circulating commodities with prices calculated according to anticipated income. Derivatives are like other securities, but further distanced from production. This extra layer of abstraction caused anxiety about the growth of derivatives trading in the 1880s. If we accept Marx's understanding of stock exchange commodities, derivatives were not intrinsically distinct from any other stock or bond. Their heightened abstraction simply brought to the fore the abstraction already taking place in the trading of fictitious capital. Derivatives did however weave together unrelated 
entities, spreading risk in unexpected ways.

I contend there is an analogy between the type of abstraction that took place in McDonald/Donahue/McDonnell's stunt and that which took place in stock exchange trading, particularly derivatives. First, in a material sense, McDonald/Donahue/McDonnell's stunt derived from the already active circuit of the railroad lines, siphoning power from its wires to create further, dependent circuits.

Second, 'Prof. Arion' was a commodified identity derived from McDonald/Donahue/McDonnell's actual one. In a twist on Marx's term for stocks and securities, McDonald/Donahue/McDonnell could be described as embodying fictitious capital: Professor Arion. He was, of course, a real person with a real life to lose, yet he invested himself as his persona, and the Company held his persona to account. The 'real capital' and real person of McDonald/Donahue/McDonnell were doubled by an identity that derived from him, but was held apart - a persona that facilitated circulation. Marx writes that with the development of the credit system, 'all capital seems to be duplicated, and at some points triplicated, by the various way in which the same capital, or even the same claim, appears in various hands in different guises' ${ }^{69}$ I suggest that McDonald/Donahue/McDonnell imitated this process through his construction of self and enactment of circulation.

Third, the performer's body and life were yoked to the value of the Brooklyn Heights Railroad Company, in spite of a lack of any material connection between the two. This enabled the Company to benefit from the risk the performer bore, paralleling Martin's characterisation of derivatives as 'quick shifts in deployment of capital to leverage money-making effects' ${ }^{70}$ Such yoking together of unrelated entities was designed to capitalise on the affective economy of physical risk. 
Finally, the overt riskiness of McDonald/Donahue/McDonnell's performance made it seem as if it was an exceptional instance, set apart from everyday production and exchange. Like a derivative, the stunt seemed to be nothing more than circulation for circulation's sake, a form of excess, which ought to be removed from the system. Yet, if we accept Marx's proposition, it actually enacted the abstraction already taking place in financial systems, tapping into a much wider condition of risk inherent in the structure of commercial enterprises, including the Brooklyn Heights Railroad Company itself.

The Company was undergoing a typical trajectory in terms of financial development, indicative of emerging monopoly capitalism. It was incorporated by the Brooklyn Rapid Transit Company (apparently before the date of the performance, though this is not clear from available sources), which took over all but one of the Brooklyn trolley lines by $1900 .{ }^{71}$ J. P. Morgan himself financed this consolidation as part of his drive to organise the nation's railroads. ${ }^{72}$

The Brooklyn Rapid Transit Company was also typical of increased public participation in the stock exchange, a characteristic of modern high finance. Historian of the New York Stock Exchange, Stedman, reported that the Brooklyn railway was a 'chief public fancy' in the final years of the century, culminating in colossal growth during which the 'glowing future of this trolley road' could not be overstated. ${ }^{73}$ This gave the Company an interest in promoting itself to two overlapping publics — commuters and potential investors - connecting increasing numbers of people to its success or failure.

Immediately afterwards, Stedman explained, came the 'inevitable descent toward the level of intrinsic worth, ruining many of its too zealous friends as it fell'. ${ }^{74}$ Note Stedman's discourse of heights and falls; resistance to, and inevitability of, gravity; and 
the alignment of gravity with a natural order of value. The market's veridiction was pitted against the public's credulity, Stedman suggested, and those who took on too much risk were ruined as a result. In Stedman's logic, such falls were not only inevitable but also necessary in the eternal pursuit of real or 'intrinsic' value. For the market to function, some credulous individuals had to be the 'fall guys', who at once demonstrated the precarious interconnections of the Stock Exchange and took the blame upon themselves, momentarily releasing everybody else from interconnection by demonstrating their individual lack of skill and judgment. ${ }^{75}$ The fall guy's fall instilled a sense of equilibrium, masking systemic precarity.

The Brooklyn Heights Railroad Company's distribution of blame following the failed high wire cycling act was a literalisation of Stedman's market logic. In spite of the Company organising the performance and standing to benefit from its successful completion, in the event of an accident, McDonald/Donahue/McDonnell merely demonstrated his own excessive tendencies and failure to live up to 'Prof. Arion's' contracted promise. In Seltzer's terms, the accident presented a macabre romance of the market in machine culture.

Both Stedman and Marx imply that fall guys had a capacity to reveal what was 'real' and what was not. For Stedman this meant restoring 'real' value rather than the inflated prices brought about by an excitable public and reckless investors. Marx's position might be seen as superficially similar to this, but Marx would have taken the critique much further: such speculative 'excess' was the financial system revolving confusedly about itself, because it was systemically derived from - yet adrift from — production and 'real' capital. Rather than restoring equilibrium, a crisis, or fall, instead demonstrated a consistent state of abstraction and derivation of value. 
McDonald/Donahue/McDonnell's act certainly revealed what was 'real' in another sense. By literalising circulation and taking on extreme risk,

McDonald/Donahue/McDonnell performed circulation as a social relation, embedded in class hierarchy. For who would take such a risk? From what little can be gathered about McDonald/Donahue/McDonnell, we can ascertain that he was probably a first or second-generation Irish immigrant, who occupied a precarious enough social and financial position for the job to be worth it.

Russo's account of stigmatisation evokes Martin's description of the way in which financialized cultures divide populations into 'those able to avail themselves of wealth opportunities through risk taking and those who are considered 'at risk." ${ }^{76}$ Risk in the present, Martin argued, has come to serve a 'moral function' by distinguishing between those with the capacity to embrace risk from 'those relegated to being bad risks. ${ }^{, 77}$ In late nineteenth-century New York, a moral, individually situated conception of risk was frequently employed, but the commentary surrounding McDonald/Donahue/McDonnell's performance indicates that this view was becoming increasingly inadequate in the new era of corporate industrial capitalism. In spite of the Company holding McDonald/Donahue/McDonnell solely responsible for his actions, discussions concerning electricity and futures demonstrate that many were alive to the fact that more and faster circulation with increased connectivity and attendant risk was the direction of travel - was in fact necessary to the running of that pillar of modernity, the Stock Exchange. Such conditions required new conceptions of how risk could be understood and managed as a collective. They also spawned fantasies of autonomous, individual risk-takers, who could relieve everybody of collective precarity. 
The recognition of stunts as a form in the late nineteenth century perhaps reflects new understandings of how risk and value related to one another, and how affective economies intersected with financial ones (through advertising for example). To a greater extent than 'circus', the word 'stunt' denotes anxiety regarding the extent to which an act and the value it creates is 'real'. This makes stunts particularly vivid examples of conflicts between conceptions of derived value and derived reality, and an opposing view put forward by Martin, who argues that dance's creation of value demonstrates a need to reject a 'nefarious dichotomy between the real and the fictitious' and move beyond it. ${ }^{78}$ While stunts such as McDonald/Donahue/McDonnell's demonstrated the extent to which bodies and identities could be abstracted, they also retained the complexity and ambiguity of embodied, performed action, in which the fictitious and the real were near impossible to prise apart. It is this twin pull of stunt performances - their simultaneous invocation of reality, and rejection of it - which makes stunts and high finance worthy of comparison, and stunts prime examples of value abstractions in embodied motion. 
1 The first lines in Brooklyn to be run on electricity were opened in May 1892 (Brian J. Cudahy, How We Got To Coney Island: On the Development of Mass Transportation in Brooklyn and King's County (New York: Fordham University Press, 2002), p. 144). However, in 1898, Brooklyn lines were still in the process of being electrified (Anon., 'Equipment of the Brooklyn Elevated Railway, Brooklyn', Street Railway Journal, 1 March 1898, 14:3, American Periodicals, p. 168).

2 The World named him as Frank McDonald (Anon., 'From Blazing Wheel to Death', World, 2 August 1897, p. 1); the Tribune as Frank Donahue (Anon., 'Hundreds Saw Him Killed', New York Tribune, 2 August 1897, p. 1); and the Brooklyn Eagle as D.H. McDonnell (Anon., 'Died From Electric Shock', Brooklyn Daily Eagle, 2 August 1897, p. 12). The Eagle also included a portrait.

3 Peta Tait, Circus Bodies: Cultural identity in aerial performances (London and New York: Routledge, 2005), p. 9.

${ }^{4}$ Anon., 'Died From Electric Shock', Brooklyn Daily Eagle, 2 August 1897, p. 12.

${ }^{5}$ Anon., 'Cycling On A Live Wire', Brooklyn Daily Eagle, 30 July 1897, p. 4.

${ }^{6}$ Anon., 'At the Chutes', San Francisco Call, 24 November 1896, p. 11.

${ }^{7}$ Anon., 'Hundreds Saw Him Killed', New York Tribune, 2 August 1897, p. 1.

${ }^{8}$ Anon., 'Died From Electric Shock', Brooklyn Daily Eagle, 2 August 1897, p. 12.

${ }^{9}$ Ibid.

10 Ibid.

11 Ibid.

12 Ibid.

13 Thomas Postlewait, 'The Theatrical Event', in The Cambridge Introduction to Theatre Historiography (Cambridge: Cambridge University Press, 2009), pp.117-154, p. 121 and 119. 
${ }^{14}$ Nicholas Ridout and Rebecca Schneider, 'Precarity and Performance: An Introduction', TDR (The Drama Review), 56:4 (2012), 5-9, 5-6.

${ }^{15}$ Randy Martin, 'A Precarious Dance, a Derivative Sociality', TDR (The Drama Review, 56:4 (2012), $62-77,65$.

${ }^{16}$ Martin, 'A Precarious Dance, a Derivative Sociality', p. 66.; Randy Martin, An Empire of Indifference: American War and the Financial Logic of Risk Management (Durham and London: Duke University Press, 2007), p. 3.

${ }^{17}$ Karl Marx, Capital: A Critique of Political Economy, trans. by David Fernbach, 3 vols (London: Penguin Books, 1992), III, p. 596.

18 Tait, Circus Bodies, p. 16; Anon., 'Hero of 200 Ascensions', St Paul Daily Globe, 17 April 1892, p. 14.

${ }^{19}$ Anon., 'John Robinson’s Big Shows Combined', Eaton Democrat, 12 April 1883, p. 2.; Anon,

'Forepaugh \& Samwell's Show', Memphis Appeal, 19 October 1886, p. 5.; S. L. Kotar and J. E. Gessler, The Rise of the American Circus, 1716-1899 (Jefferson, North Carolina and London: McFarland, 2011), p. 200.

${ }^{20}$ Anon., 'Alferetta Adair in her High Wire Bicycle Act', Holt County Sentinel, 2 September 1898, p. 4.; Anon., 'The Great Street Carnival', Audubon County Journal, 4 October 1890, p. 3.; Anon., 'Big Civic Parade', Wichita Daily Eagle, 24 September 1899, p. 3.; Anon., 'Barrett's Great Circus and Menagerie', Salt Lake Evening Herald, 11 June 1885, p. 4.; Anon., 'A Colossal Combination', Opelousas Courier, 7 November 1899, p. 3.; Kotar and Gessler, The Rise of the American Circus, p. 10; Anon., 'Old John Robinson's Gigantic Union of Shows', Salt Lake Herald, 13 July 1882, p. 1.; Anon., 'Wonders of the World!', Guthrie Daily Leader, 4 October 1898, p. 3.; Anon., 'John Robinson's Big Shows Combined', Semi-weekly Miner, 14 July 1883, p. 4.; Anon., 'Chutes and Zoo', San Francisco Call, 25 September 1898, p. 29. 
21 Matthew Wittman, Circus and the City: New York, 1793 - 2010 (New Haven and London: Yale University Press, 2012), p. 73.

22 Stoddart, p. 35-6.

23 Anon., 'John Robinson's Big Shows Combined', Semi-weekly Miner, 14 July 1883, p. 4.

24 Stoddart, Rings of Desire, p. 96.

${ }^{25}$ Anon., 'The Great Street Carnival', Audubon Country Journal, 4 October 1900, p. 3.

26 Janet M. Davis, The Circus Age: Culture and Society Under the American Big Top (Chapel Hill and London: University of North Carolina Press, 2002), p. 21.

27 Davis, The Circus Age, p. 10; 'When shares of the Mohawk \& Hudson Railroad were first traded [...] in 1830, a new generation of corporations relying on securities markets was born. As the railroads grew, everyone wanted to participate in this national project' (Walter Werner and Steven T. Smith, Wall Street (New York: Columbia University Press, 1991), p. 134). In the depression of 1893, forty per cent of railroad companies entered into technical bankruptcy, and financiers stepped in to salvage and organise the field: 'America's basic heavy industry emerged with chief executives who repudiated helter-skelter competition and looked toward Wall Street for strategic guidance' (Robert H. Wiebe, The Search for Order 1877-1920 (New York: Hill and Wang, 1967), p. 26).

28 Davis, The Circus Age, p. 12, 16, 21, 103 and 188 (physical stunts), p. 120 (publicity stunt); Stoddart, Rings of Desire, p. 51 and 54 (advertising stunts), p. 60 (clowning stunt).

29 Stoddart, p. 1.

30 Stoddart, Rings of Desire, p. 50.

31 Stoddart, Rings of Desire, p. 51. 
${ }^{32}$ During the advertising industry's rapid development in the last two decades of the nineteenth century, there was much experimentation with live performance and the use of bodies as media of circulation. Famous pedestrian Edward Weston circulated advertisements to fund his long distance walks (P. S. Marshall, “Weston, Weston, Rah-Rah-Rah!”: The Original Sporting Superstar?: A Critical Biography (Bloomington, IN: Authorhouse, 2012) p. 2), while Annie Kapchovsky from Boston sold space on her bloomers, bicycle and body to supplement her round-the-world cycling adventure (Anon., 'Round the World-A Riding Advertising Agency', Buffalo Express, 1 November 1894, quoted in Peter Zheutlin, Around the World on Two Wheels (New York: Citadel Press, 2007), p. 49). In 1894, advertising industry journal, Fame, criticised the 'worn out faces' of two 'live' advertisers in Boston, illustrating the complaint with glum-looking figures in top hats and jackets, the surfaces of which were covered in railroad ticket prices (Anon., 'Untitled', Fame, April 1894, p. 63-4). The same year, Fame printed a story in which an advertising copywriter dreamed of a new canvas for advertising: 'human skin!' (Anon., 'Something New At Last!', Fame, March 1894, p. 19-20). Fuelled by cheap labour and a flourishing new commodity in the form of media space, the advertising industry exploited bodies with experimental ebullience, which troubled distinctions between people and commodities.

${ }^{33}$ Edward Renton, The Vaudeville Theater: Building Operation and Management (New York: Gotham Press, 1918), p. 256. Vaudeville artists often called their stage acts 'stunts', e.g. Anon., 'Shows of the Week ... Pastor's', Variety, 5 May 1906, p. 9.; Advertisement, 'The Last Word in Spectacular Acrobatics and Pantomime Comedy', Variety, 12 December 1908, p. 103.

${ }^{34}$ American Dialect Society, Dialect Notes, 6 vols (Norwood, M.A.: J.S. Cushing \& Co., 1896), I, p. 400. 35 J.S. Allen, 'A Stunt', New York Journal, 31 March 1898, p. 12.; Charles Kelsey Gaines, 'A Little White Corpse', Goshen Daily Democrat, 20 September 1898, p. 6.; Anon., 'PUBLIC FIGURES ARE TURNING 
TO ATHLETICS', Sunday World, 18 July 1897, Cartoon Supplement.; Anon., 'Setting Himself a Great Stunt', Newark Daily Advocate, 15 November 1897, p. 6.

${ }^{36}$ Stoddart, Rings of Desire, p. 4.

${ }^{37}$ Frederic W. Darlington, 'Brooklyn's Electric Fountain', Street Railway Journal, 1 March 1898, 14:3, American Periodicals, p. 128.

${ }^{38}$ Stoddart, Rings of Desire, p. 80.

${ }^{39}$ Mary Russo, The Female Grotesque: Risk, Excess, and Modernity (New York and London: Routledge, 1994), p. 22. 'I call a 'strategy' the calculus of force-relationships which becomes possible when a subject of will and power [...] can be isolated from an 'environment.' A strategy assumes a place that can be circumscribed as proper [....] I call a 'tactic,' on the other hand, a calculus which cannot count on a 'proper' [....] The place of tactic belongs to the other. A tactic insinuates itself into the other's place, fragmentarily, without taking it over in its entirety, without being able to keep it at a distance' (Michel de Certeau, The Practice of Everyday Life, trans. by Steven F. Rendall (Berkeley: University of California Press, 1984), p. xix.)

40 Karl Marx, Capital: A Critique of Political Economy, trans. by Ben Fowkes, 3 vols (London: Penguin Books, 1990), I, p. 291-92.

${ }^{41}$ Georg Simmel, The Philosophy of Money, ed. by David Frisby, trans. by Tom Bottomore, David Frisby and Kaethe Mengelberg, $3^{\text {rd }}$ edn (London and New York: Routledge, 2004), p. 148. 42 Marx's formula: M (money capital) - C (Commodity capital: Labour power + means of production) ... P (productive capital) ... C' (commodity capital plus surplus value) - M' (money + additional money) (Karl Marx, Capital: A Critique of Political Economy, trans. by David Fernbach, 3 vols (London: Penguin Books, 1992), II, p. 110). 
43 Michel Foucault, The Birth of Biopolitics: Lectures at the College de France, 1978-1979, ed. by Michel Senellart, trans. by Graham Burchell (Basingstoke: Palgrave Macmillan, 2008), p. 246.

${ }^{44}$ Mark Seltzer, Bodies and Machines (New York and London: Routledge, 1992), p. 73.

45 Seltzer, Bodies and Machines, p. 14.

46 Seltzer, Bodies and Machines, p. 73.

47 Seltzer, Bodies and Machines, p. 49. Italics original.

48 Davis, The Circus Age, p. 52.

${ }^{49}$ Anon., 'A Colossal Combination', Opelousas Courier, 7 November 1899, p. 3.; Davis, The Circus Age, p. 10 and $39-40$.

50 Davis, The Circus Age, p. 12 and 37.

51 Anon., 'Hundreds Saw Him Killed', New York Tribune, 2 August 1897, p. 1.

52 Anon., 'Danger in the Wires', World, 10 May 1890, p. 1.; Anon., 'Electric Conductors in Brooklyn', Railroad Gazette, 18 January 1895, p. 36.

53 Thomas P. Hughes, 'Harold P. Brown and the Executioner's Current: An Incident in the AC-DC Controversy', Business History Review, 32:2 (1958), 143-165, 151.

${ }^{54}$ Electrical Engineer', quoted in Hughes, 'Harold P. Brown', p. 162.; Letter by F.W. Jones in Anon., 'Killing by Electricity', World, 4 January 1889, p. 2.

55 Seltzer, Bodies and Machines, p. 11.

56 Edmund Clarence Stedman, The New York Stock Exchange (New York: New York Stock Exchange Historical Company, 1905), p. v-vi.

57 Stedman, The New York Stock Exchange, p. 394.

58 Suzanne de Brunhoff, Marx on Money, trans. by Maurice J. Goldbloom, rev edn (London and New York: Verso, 2015), p. 35. 
59 Martin, 'A Precarious Dance, a Derivative Sociality', p. 64.

60 Martin, 'A Precarious Dance, a Derivative Sociality', p. 64.

61 Anon., 'Gambling in Crops, Petroleum, Etc.', Bankers' Magazine and Statistical Register, August 1883, 38:2, American Periodicals, p. 87.

${ }^{62}$ Anon., 'Should the Exchanges Be Abolished?', Bankers' Magazine and Statistical Register, August 1884, 39:2, American Periodicals, p. 88.

63 Martin, 'A Precarious Dance, a Derivative Sociality', p. 64; Martin, An Empire of Indifference, p. 11.

64 Anon., 'Banking and Financial Items: Publisher's Notice', Bankers' Magazine and Statistical

Register, September 1882, 37:3, American Periodicals, p. 230.

65 'Gambling in Crops, Petroleum, Etc.'; Anon., 'Options In Produce’,

Bankers' Magazine and Statistical Register, October 1883, 38:4. American Periodicals, p. 252.

${ }^{66}$ Anon., 'Speculation and Business', Bankers' Magazine and Statistical Register, August 1882, 37:2, American Periodicals, p. 85; 'Gambling in Crops, Petroleum, Etc.'

${ }^{67}$ Anon., 'Speculation and Business', Bankers' Magazine and Statistical Register, August 1882, 37:2, American Periodicals, p. 85.

${ }^{68}$ Anon., 'Options in Produce', Bankers' Magazine and Statistical Register, October 1883, 38:4, American Periodicals, p. 252.

${ }^{69}$ Marx, Capital, III, p. 601.

${ }^{70}$ Martin, An Empire of Indifference, p. 10.

${ }^{71}$ Brooklyn Heights was initially taken over by a holding company called the Long Island Traction Company in 1893. Long Island then used the company to lease many more lines. In 1895, Long Island was reorganised as the Brooklyn Rapid Transit Company. By 1900, this company had control of all but five of the elevated rapid transit lines (Roger P. Roess and Gene Sansone, The Wheels That 
Drove New York: A History of the New York City Transit System (Springer: Springer-Verlag, 2013), p. 77).

${ }^{72}$ Jean Strouse, Morgan: American Financier (London: The Harvill Press, 1999), p. 312-322.

73 Stedman, The New York Stock Exchange, p. 381.

${ }^{74}$ Stedman, The New York Stock Exchange, p. 382-383.

75 The term 'fall guy' came into use in slang in the first few years of the twentieth century in the United States to mean 'easy victim' or 'one who 'takes the rap' for others' ("fall, n.1." OED Online.

Oxford University Press, September 2015. Web. 2 December 2015).

${ }^{76}$ Martin, An Empire of Indifference, p. 8.

77 Martin, An Empire of Indifference, p. 21.

${ }^{78}$ Martin, 'A Precarious Dance, a Derivative Sociality', p. 66. 